Board Roles in Small and Medium-Sized Family Businesses:

performance and importance

Peer-reviewed author version

VAN DEN HEUVEL, Jeroen; VAN GILS, Anita \& VOORDECKERS, Wim (2006)

Board Roles in Small and Medium-Sized Family Businesses: performance and

importance. In: Corporate Governance: An International Review, 14(5). p. 467-485.

DOI: $10.1111 / j .1467-8683.2006 .00519 . x$

Handle: http://hdl.handle.net/1942/1528 


\section{Board Roles in Small and Medium-Sized Family Businesses:}

\section{Performance and Importance}

\section{Abstract}

The board of directors is regarded as one of the most imperative governance mechanisms in small and medium-sized family firms. Empirical studies examining both the roles these boards fulfil in a family business context, as well as evaluating the CEO's perceived importance of these roles, are scarce. Founded by a range of conceptual and multi-theoretical board role definitions, this paper contributes to the literature by empirically determining board roles. Furthermore, the importance of these board roles and differences between the board's performance and perceived importance are assessed. The results show it is indispensable to differentiate between two aggregated roles that boards in small and medium-sized family firms perform: control and service. The control role is predominantly based on agency theory, whereas the service role includes multiple theoretical perspectives. The CEOs of the family firms perceive the service role of the board as most important. However, in order to direct succession and to compensate for the owner/manager's altruistic behaviour, the board's control role should not be neglected. The acknowledgement of these two aggregated board roles and their importance may enhance future research on board roles within specific contexts.

Key Words: board role, governance, board of directors, SME, family firm 
Jeroen Van den Heuvel is Ph.D. candidate at the department of business administration at Hasselt University. His research interests include governance in small and medium-sized family firms. (corr. author; e-mail: jeroen.vandenheuvel@uhasselt.be)

Dr. Anita Van Gils is assistant professor in the department of Organisation and Strategy at Maastricht University. Her research interests include strategic alliances, entrepreneurship and governance in small and medium-sized firms.

Dr. Wim Voordeckers is assistant professor in the department of business administration at Hasselt University. His research interests include small business finance and governance in family firms.

Hasselt University

att. Jeroen van den Heuvel

Faculty of Applied Economic Sciences

Agoralaan - building D

B-3590 Diepenbeek

Belgium

Hasselt University

att. Jeroen van den Heuvel

Faculty of Applied Economic Sciences

Agoralaan - building D

B-3590 Diepenbeek

Belgium

Hasselt University

att. Jeroen van den Heuvel

Faculty of Applied Economic Sciences

Agoralaan - building D

B-3590 Diepenbeek

Belgium

- As of June 15, 2005, the name of the Limburg University Centre changed in Hasselt University. Therefore, the corresponding address changed compared to our first submission.

Word count: abstract: 187

body: $\quad 5056$

references: 1900 (when incl. digits as words; 2403) 


\section{Introduction}

A considerable amount of research within the corporate governance field has focused on boards of directors. This body is regarded as one of the major elements in the governance framework, influencing firm outcomes (Pearce and Zahra 1992, Johnson, Daily and Ellstrand 1996, Forbes and Milliken 1999, Hillman and Dalziel 2003). In the past, the vast majority of research in this area was conducted in a large firm context (Charkham 1995). However, current researchers and managers also acknowledge the importance of well-functioning boards of directors in small and medium-sized private firms, as good governance practices seem to result in the creation of firm value, improved company structures, (financial) results and firm continuity (Zahra and Pearce 1989, Borch and Huse 1993, Johannisson and Huse 2000).

Within the small and medium-sized business population, family businesses are the predominant form of organisation (Donckels and Fröhlich 1991, Corbetta and Montemerlo 1999). They provide extensive contributions to gross national products, job generation and wealth creation (Beckhard and Dyer Jr. 1983, Shanker and Astrachan 1996, Kelly, Athanassiou and Crittenden 2000, Feltham, Feltham and Barnett 2005). Nevertheless, in organisational and managerial research, this family business group is largely underrepresented (Schulze, Lubatkin, Dino and Buchholtz 2001, Dyer 2003, Steier, Chrisman and Chua 2004). Moreover, most of the governance studies within family businesses still focus on large (publicly-traded) family firms, while the vast majority of these firms are smaller (Handler 1989, Johannisson and Huse 2000). The focus on large businesses contrasts with the claim 
that the role of the board of directors is more decisive for smaller family firms (Castaldi and Wortman 1984, Nash 1988, Ward and Handy 1988, Ward 1992). Corbetta and Tomaselli (1996) claim that "a well-functioning board of directors can in fact be a critical resource for both family and business...”. Therefore, our study aims to contribute to the existing literature by empirically investigating board role performance and importance in a small and medium-sized family firm context.

Research on board functioning within an SME-context is considered fragmented (Huse 2000) and is relatively in its infancy. Although a large number of authors have studied the roles of an SME's board, our literature review clearly illustrates that conceptual and methodological improvements could further enhance this field of study. Additional empirical research studying different (legal) contexts and examining different contingencies is needed, in order to validate the board roles identified in the literature. Moreover, existing research almost solely focuses on board role performance. None of the empirical studies has examined the importance of different board roles within the context of small and medium-sized family firms. In this type of firms the majority of the businesses are highly dependent on a single decision maker; in most cases the owner/manager (Daily and Dollinger 1992, Harris, Martinez and Ward 1994, Feltham, et al. 2005). Studying the CEOs' perception of the importance of board roles clarifies why CEOs opt for good governance structures. Once we know which role(s) the family firm CEOs perceive as most important, advice can be formulated in relation to improvements in board performance. Therefore, the goal of this paper is threefold: 1) to empirically investigate which roles boards in small and medium-sized family firms do perform, 2) to study which of the roles identified is 
(are) perceived as being most important by the CEO's of these family businesses and 3) to formulate advice for improvements in board performance.

The paper is structured as follows. The first part offers an overview of the literature and definitions of board roles, both in general as well as in the context of small and medium-sized firms and family businesses. Subsequently, the methods are described by explicating the sample, the design and the procedures followed. Thereafter, the empirical results are put forward. Finally, the conclusion includes a discussion of the findings and suggestions for further research.

\section{Board role literature}

\section{General literature}

Board role research is mainly characterised by the conceptual development of board roles, based on a range of organisational theories such as agency, resource dependence, resource-based, strategic leadership, stewardship, social network and institutional theory (Fried, Bruton and Hisrich 1998, Dalton, Daily, Johnson and Ellstrand 1999, Daily, Dalton and Cannella 2003, Hillman and Dalziel 2003, Lynall, Golden and Hillman 2003). In the context of this paper, board roles are defined as aggregated board tasks, identified on the basis of - or related to - specific theoretical perspectives. Board tasks are the different sub-activities boards fulfill in practice. A well-structured overview of the impact of different theories on the roles boards have to fulfil is provided by Hung (1998) and Alberti (2001). However, Gabrielsson and Huse (2005) show that a combination of different theories is needed to explain the roles boards fulfil. Within academic publications, conceptual development based on 
different theories has lead to ambiguity in board role definitions. Four articles from leading management journals (Pearce and Zahra 1992, Johnson, et al. 1996, Hillman, Cannella and Paetzold 2000, Hillman and Dalziel 2003) and one book (Finkelstein and Hambrick 1996) are selected to illustrate this fact, as these publications provide a comprehensible set of board role definitions from multiple theoretical perspectives. The board role definitions posed by these scientific publications are presented in table 1.

$* * * * * * * * * *$ Insert table 1 about here

In 1989, Zahra and Pearce made a seminal contribution to board role research, by reviewing extant board studies in an integrative perspective. In their 1992 paper, they describe three sets of interrelated roles played by boards in contemporary organisations: service, strategy and control (Pearce and Zahra 1992 p.412). Later, Finkelstein and Hambrick (1996) identify only two roles boards of directors perform in the organisation, without providing labels for these roles (see table 1). In the same year, Johnson, Daily and Ellstrand (1996) delineate three main roles for boards of directors; the control role, the service role, and the resource dependence role. Furthermore, Hillman, Cannella and Paetzold (2000) differentiate between the agency or control role and the resource dependence role. Subsequently, Hillman and Dalziel (2003) describe the monitoring function and the provision of resources function.

Balancing these publications, it is clear that the labels and contents of the roles are not in all cases similar. A comparison of the definitions of these publications on - what is generally called - the control role, shows a relatively high level of similarity. All four regard agency theory as the basis of the control role, as they emphasise the principal- 
agent problem in which the fiduciary role of the board of directors in protecting shareholders' interests is essential (Fama and Jensen 1983). However, contrary to the similarity in the control role definition, no general accepted definition seems to exist for the service, strategy or resource dependence role. Service, strategy and resource dependence related tasks are grouped within different board roles, depending on the definition and theoretical perspectives used by the authors.

This analysis confirms earlier research findings of Lipton and Lorsch (1992), indicating that board roles and their definitions are surrounded by ambiguity. Apparently, the general literature has not brought clarity to this issue in the past decade. The next section of this paper presents an overview of board role studies executed within a SME and/or family business context.

\section{SME and family businesses literature}

A systematic search process was conducted to provide an overview of the knowledge developed in this field of study ${ }^{\mathrm{i}}$. Table 2 provides the SME or family firm studies identified, including the major research findings, theoretical perspectives, research characteristics, methodology and sample of each publication. The remainder of this section reviews these issues to arrive at a conclusion which indicates suggestions for further development in the field of board roles in small and medium-sized family businesses.

$* * * * * * * * * *$ Insert table 2 about here 
Board role or task studies are not new within the SME and family firm research society. Already in 1948, it was stated that boards can be tapped for advice and counsel, thus pointing to the value boards can add to smaller businesses (Mace). In the period 1980-2004 research on governance issues in these firms has been spurred; more than 30 articles discuss board role or task issues. Whereas these studies were mainly of a prescriptive or anecdotic nature in the 1980s, more empirical and conceptual studies have been published recently.

The vast amount of the studies describes the board's role performance within an SME context. Of those articles that focus on family firms, only two (Davis and Pett 2000, Johannisson and Huse 2000) explicitly study board roles in smaller family firms. In most studies, the survey was directed towards the CEO; a few studies (Ford 1988, Borch and Huse 1993, Huse 1993, Johannisson and Huse 2000) questioned both the CEO and a member of the board. Agency theory is the dominant theoretical paradigm used, sometimes in combination with the resource dependence perspective and/or the resource-based view.

The collection of publications discussing board roles in SMEs and family businesses is valuable as it has initiated and extended the available knowledge on the subject. Moreover, it has proposed an agenda for further research. However, our literature review illustrates that conceptual and methodological improvements could further enhance this field of study. First of all, it would be beneficial to clearly define the concepts studied. The articles included in table 2 - describing "what a board is expected to do' - label it as board tasks (Fox 1982, 1983, Barach 1984, Fox 1984, Daily and Dalton 1993, Corbetta and Tomaselli 1996, Gabrielsson and Winlund 2000, Gabrielsson and Huse 2002, Van den Berghe and Carchon 2002), board functions 
(Castaldi and Wortman 1984, Ford 1988, Johannisson and Huse 2000, Markman, Balkin and Schjoedt 2001, Mustakallio, Autio and Zahra 2002), board roles (Ward and Handy 1988, Whisler 1988, Deakins, O’Neill and Mileham 2000, Huse 2000, Gabrielsson and Huse 2005), board involvement (Rosenstein 1988, Borch and Huse 1993), board activity (George, Wood Jr. and Khan 2001) and area of help (Schwartz and Barnes 1991). Often, definitions of these concepts or relationships between these items are not specified. A second improvement could be made in labelling the specific board roles. Despite the fact that authors base their analysis on the same theoretical perspectives, board roles are given different names. Starting from agency theory, authors refer to the control (Huse 1993, Gabrielsson and Winlund 2000) or the monitoring role (Deakins, et al. 2000, Johannisson and Huse 2000, Markman, et al. 2001, Mustakallio, et al. 2002). Resource dependence and resource-based perspectives result in the board's service (Gabrielsson and Winlund 2000), advice (Deakins, et al. 2000, Johannisson and Huse 2000), council (Mustakallio, et al. 2002) and strategy role (Deakins, et al. 2000, Gabrielsson and Huse 2002). A third and important improvement for theory building would be to find consensus on how a specific board role should be measured. Huse (1993) uses eight questions to cover the control role, while Gabrielsson and Winlund (2000) use a 10-item scale to measure the same concept. Mustakallio et al. (2002), studying the monitoring role derived from agency theory, use once again a different five-item scale. Finally, comparing the results of the studies on board roles or tasks is difficult, as different units of analysis are used. Some authors examine the added value of the board as a group (Castaldi and Wortman 1984, Borch and Huse 1993, Huse 1993, Gabrielsson and Winlund 2000, Johannisson and Huse 2000, George, et al. 2001), while others study the contribution of individual board members as outside directors (Whisler 1988, Schwartz and Barnes 1991, 
Gabrielsson and Huse 2005) or venture capital representatives (Deakins, et al. 2000, Gabrielsson and Huse 2002). Additional research, clearly stipulating the unit of analysis, would advance our knowledge on the added value of different types of boards.

The analysis of both the general and the SME/family business literature show that until now, no consistent patterns of board roles and definitions have been defined on an empirical basis, neither in general (see table 1), nor for the population of SMEs and family businesses specifically (see table 2). Moreover, all empirical SME or family business publications study board role performance or involvement. In other words, they try to analyse what boards or individual board members are effectively doing or contributing to the firm. None of the studies has investigated what the CEO's of these small or medium-sized family firms expect from their board, or which tasks or roles they perceive as most important. As many of the family businesses are entirely owned by the CEO and/or his (her) family, the CEO is the person who has the power to stimulate the functioning of his (her) board of directors, or to make it a "rubberstamp-board" (Mace 1971). Taking this background into account, our study adds value to the existing literature by examining both board role performance and board role importance. First of all, based on generally accepted board role definitions, we delineate a set of empirically based roles that are performed by boards of directors in small and medium-sized family firms. Secondly, we examine which tasks and roles the CEO perceives as being most important. Third, a comparison between the board role performance and level of board role importance is made. Using the data from these two questions, we are able to indicate on which issues board role performance should be improved. 


\section{Methods}

\section{Sample}

The empirical data presented in this paper are derived from a wider study exploring characteristics, strategic and environmental issues, management and board composition, governance, succession and performance in a representative sample of Flemish family businesses. As definitions of family businesses abound in the literature and definitional ambiguities persist (Chua, Chrisman and Sharma 1999), we first selected an operational definition for identification of family businesses that is based on the common selected criteria of ownership, management control (Chua, et al. 1999) and the CEO's perception (Westhead and Cowling 1998). In this study, a firm is classified as a family firm, if: (1) at least fifty percent of the shares are owned by the family, and the family is responsible for the management of the company, or (2) at least fifty percent of the shares are owned by the family, the company is not familymanaged, but the CEO perceives the firm as family firm, or (3) family-ownership is less than fifty percent, the company is family managed, the CEO perceives the firm as a family firm and a venture capital or investment company owns at least fifty percent of the shares. Representative data were obtained as different size classes of family firms were selected based on their importance within the Belgian economy, and responses were not biased versus smaller or larger firms ${ }^{\mathrm{ii}}$. All firms in the sample were privately-owned companies that employed at least five people and were situated in the Flemish part of Belgium. 
In total, 3400 firms were randomly selected from a family-business database and a survey was mailed to the CEO's. After sending a reminder, 311 surveys were returned (9.2\%), of which 295 contained sufficient data to be included in the analysis. Of these 295 family firms, 246 (83\%) were family-owned and managed, 41 (13.9\%) familyowned but not family-managed and 8 family-managed but not family controlled. Furthermore, 9 observations were excluded because they did not fit the European definition of a small and medium-sized enterprise ${ }^{\text {iii }}$. Finally, 286 observations were found useful and complete enough to be included in the database. Sample characteristics of the data used in the principal component analysis are specified in table 3 .

$* * * * * * * * * *$ Insert table 3 about here $* * * * * * * * * *$

Furthermore, in order to interpret the data, it is important to know that the form of the Belgian governance system resembles the Latin one-tier structure (De Jong 1997; Weimer and Pape 1999). ${ }^{\text {iv }}$

\section{Design and procedures}

\section{Board role performance}

As stated in the introduction, the first objective of this paper is to identify roles performed by boards in small and medium-sized family firms. This is achieved conducting a principal component analysis on the board's performance of 11 board tasks (see table 4, column 3).

$* * * * * * * * * *$ Insert table 4 about here 
Given the methodological problems and ambiguity in board role definitions encountered in the general literature as well as the SME and family business literature, these eleven tasks are derived from those publications discussed in table 1, as these studies are accepted in leading management journals and they use multiple theoretical perspectives. Although purposely a limited number of publications is included, we certainly do not want to be disrespectful to other studies (e.g. Mace 1971, Jensen and Meckling 1976, Pfeffer and Salancik 1978, Wernerfelt 1984, Donaldson and Davis 1991, Judge and Zeithaml 1992, Westphal 1998, Forbes and Milliken 1999, McNulty and Pettigrew 1999, Carpenter and Westphal 2001, Golden and Zajac 2001, Stiles 2001, Daily, et al. 2003, Lynall, et al. 2003). Table 1 shows how the specific board tasks in the questionnaire are derived from the board roles as developed in the general literature. Evaluating or controlling management performance (task_7), direct succession problems (task_4), maximize shareholder value (task_6), determine salary/compensation of management (task_8), select new managers (task_9) and determine management responsibilities (task_10) are derived from agency theory. The resource dependence perspective, the resource-based view and the strategic leadership perspective are at the basis of the four other tasks: building organisational reputation (task_1), advising management (task_2), taking care of access to extra resources (task_3), formulating/ratifying organizational strategy (task_5) and networking and maintaining relations (task_11). These tasks were purposely mixed at random in the questionnaire to reduce association bias that could occur between conceptually related tasks as much as possible. Given the diverging board role definitions with accordingly ambiguous contents (Lipton and Lorsch 1992) and the relatively premature stage of empirical board role research in 
small and medium-sized family firms (Huse 2000), the principal component analysis at hand is conducted from an exploratory-descriptive perspective. The components are derived as a representation of the roles in the underlying data structure.

After exploration of the data and verification of the assumptions ${ }^{\mathrm{v}}$ in principal component analysis, the aggregated board roles are derived from the eleven specific board tasks, applying two criteria: the latent root criterion $(>1.0)$ and an analysis of the inflection point of the scree plot criterion ${ }^{\mathrm{vi}}$. Furthermore, listwise exclusion is used to deal with missing data ${ }^{\text {vii }}$. Therefore, the number of observations is reduced from 286 in the full sample to 202 complete observations. Further analysis of the omitted observations shows that these family firms possessed a paper or 'rubberstamp' board, which means that their boards are relatively inactive. In addition, taking into account the shared correlation that the underlying components (or board roles) are expected to have, the factor solution is rotated using oblique rotation ${ }^{\text {viii }}$ in order to optimise and derive a more comprehensible factor solution. This follows the argument that a board, which is more active on one component (role), will probably show more overall activity and thus will also be more active on other roles (Gabrielsson and Winlund 2000).

\section{Board role importance}

In order to test the CEOs' perception on the importance of the different board tasks for their firm, the respondents were asked to report the importance - for each of these 11 board tasks - on a five-point Likert scale (see table 4, column 4). Based on these scores, conclusions can be drawn in relation to the importance of the different board tasks and roles in a small or medium-sized family firm context. Moreover, average 
importance data will be compared to the average performance data, in order to verify if board functioning can be improved.

\section{Empirical results}

\section{Board role performance}

Application of the criteria and procedures discussed in the methods part of this paper, leads to an extraction of two components for which all variables load significantly ${ }^{\text {ix }}$ on only one of the two factors. Furthermore, for both components, the Cronbach's alpha's (respectively .83 and .78) demonstrate an ample level of internal consistency (Robinson, Shaver and Wrightsman 1991). Table 5 shows the components, along with the item titles, followed by their respective factor loadings on each component.

\footnotetext{
$* * * * * * * * * *$ Insert table 5 about here $* * * * * * * * * *$
}

Analysing the first component, it becomes clear that all items of this component lead to control issues stemming from an agency perspective. Within this perspective, also the labels monitoring role, management control model and corporate control role have been used (Mace 1971, Drucker 1981, Fama and Jensen 1983, Boyd 1990, Johnson, et al. 1996). The first component in table 5 is labelled the 'control' role. Other studies executed within an SME or family firm context (Huse 1993, 1994, 1998, Deakins, et al. 2000, Johannisson and Huse 2000, Gabrielsson and Winlund 2000, Markman, et al. 2001, Mustakallio, et al. 2002) also acknowledge the boards control/monitoring role or function. 
In contrast to the items of the control role, the relation between the items of the second component and one specific board role is not that obvious. Table 1 illustrates that the items of which the second component consists, are often not bound to one specific role, but appear to be part of multiple roles (except the control role) depending on the definition and the item. This is analogous with the argument that the range and depth of service activities available to the boards are likely to be greater (Castaldi and Wortman 1984, Judge and Zeithaml 1992) and more important for small firms (Hambrick and Finkelstein 1987, Gorman and Sahlman 1989). Related to this line of reasoning, some researchers have stated that the board in small and mediumsized family firms should be viewed from a resource based approach in which the boards are not only resources through their network, liaison role and externally focused activities but also through their competencies of counsel and advice, among others (Barney 1991, Grundei and Talaulicar 2002, Huse 2005b). Table 2 illustrates that several researchers studying board roles within the SME or family firm population have emphasized the board's involvement in this service-related role; however, different role names have been proposed (Deakins, et al. 2000, Gabrielsson and Winlund 2000, Johannisson and Huse 2000, Gabrielsson and Huse 2002, Mustakallio, et al. 2002). In this paper, the diversified set of roles - 'resource dependence role', 'strategy role' and 'service role' (all included in the second component) - are conjoined into one role, labelled 'service' role.

\section{Board role importance}

The board role importance data, presented in table 6 , illustrate that the family firm CEOs perceive the service role as more important than the control role. With the 
exception of one task (getting access to additional resources), all service tasks also received a higher average importance than the control tasks.

$* * * * * * * * * *$ Insert table 6 about here $* * * * * * * * * *$

Different theories can be used to explain the importance of the service role within small and medium-sized family firms. The family firm CEOs seem to perceive their boards as an intellectual and reputational resource, networking and maintaining relations as well as providing advice when needed. Besides resource-based and resource dependence arguments, another explanation for the higher importance of the service task could be found in the theory on cognition. It is stated before that many family businesses are highly dependent on the owner-manager. Feltham et al. (2005) illustrated for a sample of Canadian family-owned businesses that more than half of these firms had two or fewer key managers. Moreover, 65 percent of the CEOs indicated that they made all the major decisions in at least three out of five functional business areas. However, the business environments in which these family managers have to operate has become increasingly complex, unpredictable and unstable (SadlerSmith 2004). In order to cope with this complexity and uncertainty, entrepreneurs and small business managers seem to use specific cognitive styles as well as decisionmaking biases and heuristics. Intuitive decision making (Allinson, Chell and Hayes 2000, Sadler-Smith 2004), overconfidence (Busenitz and Barney 1997, Simon, Houghton and Aquino 2000, Forbes 2005) and representativeness (Busenitz and Barney 1997) are some of the cognitive aspects characterizing the CEOs in these firms. Research on performance implications of these characteristics is still scarce. Nevertheless, Busenitz and Barney (1997) suggest that it is possible that the more 
extensive use of heuristics may be a great advantage during the start-up years of a business; however, it can also lead to the demise of a business as a firm matures. A well-functioning board of directors, including outsiders, could add value by advising the CEO and making the decision-making process less intuitive. Jain et al. (1980) also stipulated that board members have to provide expertise to compensate for small companies' managerial deficiencies.

The fact that the control function is perceived as less important can easily be explained by studying the ownership structure of the firms in the sample (see table 3 ). On average, the family manager(s) own(s) $86 \%$ of the shares and their family $12 \%$. As such, the CEOs do not want too much interference from the board on control tasks as determining management responsibilities or salaries. This does not imply that the board can neglect the control role within small and medium-sized family businesses. First, as the CEOs have indicated, boards have an important task in relation to the succession process. Neubauer and Lank (1998) also included succession in their list of important governance tasks in family businesses. Secondly, although agency costs seem to be reduced within family firms because of the alignment of the ownermanager's interests, parental altruism is assumed to offset the agency benefits of family owner management (Schulze, et al. 2001, Lubatkin, Schulze, Ling and Dino 2005).

A comparison of the board role importance data with the board role performance data (see table 6) results in the conclusion that the CEOs acknowledge the performance of their boards can be improved, both in relation to the control and the service role. For the control role, directing succession and controlling management performance needs 
to be improved most, while for the service role these are building organisational reputation and providing strategic advice.

\section{Conclusion and discussion}

Boards in Belgian small and medium-sized family businesses perform two aggregated board roles: control and service. The control role is mainly based on agency theory, whereas the service role embraces several theoretical perspectives. These findings seem to confirm earlier research executed for the population of SMEs and/or family businesses. Some studies (Deakins, et al. 2000, Johannisson and Huse 2000, Markman, et al. 2001, Mustakallio, et al. 2002) acknowledged the board's control or monitoring role, others have indicated the board's involvement in several servicerelated tasks (Deakins, et al. 2000, Gabrielsson and Winlund 2000, Johannisson and Huse 2000, Gabrielsson and Huse 2002, Mustakallio, et al. 2002).

CEOs of the small and medium-sized family firms perceive the service role as more important than the control one. Besides resource-based and resource dependence arguments, we indicate the potential explanatory value of the theory of cognition. As stipulated by Jain et al. (1980), board members might have to provide expertise to compensate for small companies' managerial deficiencies. Further research explicitly studying the influence of the CEOs' cognitive decision making style on board role performance, could advance theory on governance in small and medium-sized firms as well as family businesses. The control role was perceived as less important by the CEOs, however, family firm succession (Neubauer and Lank 1998) and the possibility 
of altruistic behaviour (Schulze, et al. 2001, Lubatkin, et al. 2005) demand a focus on both roles from all the boards' members.

According to the family firm CEOs, board performance can be improved for both the control and service role. More specifically, directing succession, evaluating management, building organisational reputation and providing strategic advice are board tasks that need improvement. Future research could benefit from questioning both the CEO and one or more members of the board. Both importance and performance perceptions could be compared, as the information obtained from such an analysis is valuable to improve the functioning of the CEO, the board and its members.

This study has stipulated the methodological problems that hamper theory development within this domain. Our approach of assembling a specific set of tasks using a multi-theoretical perspective from general board role literature has some limitations. Only eleven tasks were measured in the questionnaire, while recent publications (Gabrielsson and Huse 2005, Huse 2005a) mention other or additional ones. Further research is needed to validate and/or extend our research findings. Deductive research studies should solve the measurement problems, thereby enhancing comparability of studies and facilitating future research in this area. Inductive studies could focus on gathering a more complete list of tasks boards perform within specific contexts or taking into account specific contingencies.

We also acknowledge that this study provides a static picture of the tasks and roles that boards perform. As the problems that small and medium-sized family firms 
encounter will change during the different stages of the business and/or family life cycle (Neubauer and Lank 1998, Westhead, Howorth and Cowling 2002), longitudinal research on both board role performance as well as the CEOs' perception of the importance of these tasks can extend the findings of our study.

Finally, we note that this study is limited to Belgium and consequently, the subjects in our sample are liable to Belgian legal requirements on governance structures. Although it has been argued that the effect of national legal requirements is minimal for small and medium-sized family firms (Grundei and Talaulicar 2002), research in other geographic areas could benefit and strengthen the external validity of our results.

In view of directions for future research, the importance of studying determinants and consequences of board role behaviour as an imperative and influential part of the governance system has been designated (Pearce and Zahra 1992, Pettigrew 1992, Johnson, et al. 1996, Huse 2000). This paper shows that it is prolific to solve the methodological problems related to definitions and measurement of board tasks and roles. We propose a condensed measure of board roles which may enhance comparability of studies, thereby facilitating future research in this area Furthermore, a better understanding of the relationship between particular situations and contexts (e.g. organisational life cycle), desirable board role behaviour, and board level or firm level outcomes, would be valuable in order to enlarge our understanding of the board's function and value for small and medium-sized family businesses. 


\section{Acknowledgements}

For providing financial support and the opportunity to conduct a survey in Belgian family businesses, the authors are grateful to the National Bank of Belgium and to the 'Instituut voor het Familiebedrijf' with special thanks to Mr. J. Lievens, co-founder and executive director of the latter organisation. The authors also thank the anonymous reviewers for their valuable comments and suggestions.

\footnotetext{
${ }^{\mathrm{i}}$ As a first step, using the EBSCO database, we selected the academic articles that specified the words family firm - SME - small or entrepreneurial firm in combination with the words board task(s) or board role(s). Secondly, the reference lists of the selected articles were checked in order to verify if other articles had to be included. The authors acknowledge that the list of publications in this table is non-exhaustive; for instance book publications are not included. However, the information provided in the table serves the objective to inform the reader about the knowledge developed in this research domain.

ii The sample does have a small geographical bias; a larger percentage of firms responded within the region where the university was located. Non-response analysis also indicated a small bias towards responses from firms having a functioning board of directors.

${ }^{\text {iii }}$ European definition of small and medium-sized firm: $(1)<250$ employees and (2) Annual turnover $<$ EUR 50 million and/or; (3) Balance sheet total < EUR 43 million.

${ }^{\text {iv }}$ It is regarded as being an insider system with a network orientation (Moerland 1995; Lannoo 1999). The majority of companies adopt a one-tier board structure, although the possibility of a dual system exists. In 2005, a non-compulsory corporate governance code for SMEs was developed, which includes a specific chapter with recommendations for family firms.

${ }^{v}$ The correlation matrix displays a moderate degree of multicollinearity $(>0.3)$ in a substantial number of interrelated sets of variables. The correlation indexes are significant at a .01 significance level for all cases. The observations-to-variables ratio being 19-to-1 is sufficient, considering the suggested ratio's of minimum five-to-one, ten-to-one, or at the highest twenty-to-one (Hair, Anderson, Tatham and Black 1998). The Bartlett test of sphericity, measuring factorability, is significant (.000) (Hair, et al. 1998). The Kaiser-Meyer-Olkin MSA value being .910 can be classified as meritorious (>.80) and indicates that "each variable is perfectly predicted without error by the other variables" (Kaiser 1970, 1974).

vi The combination of latent root and scree plot criteria provides a fairly reliable criterion for factor selection in the case of a sample of more than 200 subjects $(\mathrm{N}=202)$ and less than 20 variables $(\mathrm{X}=11)$ (Stevens 1992).

vii This is in accordance with the arguments of Arrindel and Van der Ende (1985) and Comrey (1973), stating that the observations-to-variable ratio has a minor effect on factor stability and a sample size of 200 is still labelled as 'fair'.

viii Contrary to orthogonal rotation, oblique solutions are obtained with the introduction of correlations among factors (Kim and Mueller 1978).

ix Stevens (1992) has suggested that in the case of a sample size of 200, the factor loadings in the pattern matrix must be larger than .364 to be considered significant.
} 


\section{List of references}

Alberti, F. (2001) The Governance of Industrial Districts: A Theoretical Footing Proposal, Liuc papers n.82, Serie Piccola e Media Empresa 5, 31.

Allinson, C. W., Chell, E. and Hayes, J. (2000) Intuition and Entrepreneurial Behavior, European Journal of Work and Organizational Psychology, 9(1), 31-43.

Arrindel, W. A. and Van der Ende, J. (1985) An Empirical Test of the Utility of the Observations-to-Variables Ratio in Factor and Components Analysis, Applied Psychological Measurement, 9, 165-178.

Barach, J. A. (1984) Is There a Cure for the Paralyzed Family Board?, Sloan Management Review, 26(1), 3-12.

Barney, J. (1991) Firm Resources and Sustained Competitive Advantage, Journal of Management, 17(1), 99-120.

Beckhard, R. and Dyer Jr., W. G. (1983) Managing Continuity in the Family-Owned Business, Organizational Dynamics, 12(1), 5-12.

Borch, O. J. and Huse, M. (1993) Informal Strategic Networks and the Board of Directors, Entrepreneurship: Theory and Practice, 18(1), 23-36.

Boyd, B. (1990) Corporate Linkages and Organizational Environment: A Test of the Resource Dependence Model, Strategic Management Journal, 11, 419-430.

Busenitz, L. W. and Barney, J. B. (1997) Differences between Entrepreneurs and Managers in Large Organizations: Biases and Heuristics in Strategic Decision-Making, Journal of Business Venturing, 12(1), 9-30.

Carpenter, M. A. and Westphal, J. D. (2001) The Strategic Context of External Network Ties: Examining the Impact of Director Appointments on Board Involvement in Strategic Decision Making, Academy of Management Journal, 4(4), 639-660.

Castaldi, R. and Wortman, M. S. J. (1984) Boards of Directors in Small Corporations: An Untapped Resource, American Journal of Small Business, 9(2), 1-10.

Charkham, J. P. (1995) Keeping Good Company: A Study of Corporate Governance in Five Countries. New York: Oxford University Press.

Chua, J. H., Chrisman, J. J. and Sharma, P. (1999) Defining the Family Business by Behavior, Entrepreneurship: Theory and Practice, 23(4), 19-39.

Comrey, A. L. (1973) A First Course in Factor Analysis. New York: Academic Press.

Corbetta, G. and Montemerlo, D. (1999) Ownership, Governance, and Management Issues in Small and Medium-Size Family Businesses: A Comparison of Italy and the United States, Family Business Review, 12(4), 361-374.

Corbetta, G. and Tomaselli, S. (1996) Boards of Directors in Italian Family Business, Family Business Review, 9(4), 403-421.

Daily, C. M. and Dalton, D. R. (1993) Board of Directors Leadership and Structure: Control and Performance Implications, Entrepreneurship: Theory and Practice, 17(3), 65-81.

Daily, C. M., Dalton, D. R. and Cannella, A. A. (2003) Introduction to Special Topic Forum; Corporate Governance: Decades of Dialogue and Data, Academy of Management Review, 28(3), 371-382.

Daily, C. M. and Dollinger, M. J. (1992) An Empirical Examination of Ownership Structure in Family and Professionally Managed Firms, Family Business Review, 5(2), 117136.

Dalton, D. R., Daily, C. M., Johnson, J. L. and Ellstrand, A. E. (1999) Number of Directors and Financial Performance: A Meta-Analysis, Academy of Management Journal, 42(6), 674-686.

Davis, P. S. and Pett, T. L. (2000) Governance and Goal Formation among Family Business: A Resource Dependency Perspective, The International Journal of Entrepreneurship and Innovation, 1(3), 137-149. 
Deakins, D., O'neill, E. and Mileham, P. (2000) The Role and Influence of External Directors in Small, Entrepreneurial Companies: Some Evidence on Vc and Non-Vc Appointed External Directors, Venture Capital, 2(2), 111-127.

De Jong, H. W. (1997) The Governance Structure and Performance of Large European Corporations, Journal of Management and Governance, 1(1), 5-27.

Donaldson, L. and Davis, J. H. (1991) Stewardship Theory or Agency Theory: Ceo Governance and Shareholder Returns, Australian Journal of Management, 16(1), 5064.

Donckels, R. and Fröhlich, E. (1991) Are Family Businesses Really Different? European Experiences from Stratos, Family Business Review, 4(2), 149-160.

Drucker, P. (1981) Toward the Next Economics, and Other Essays. New York: Harper \& Row.

Dyer, W. G. (2003) The Family: The Missing Variable in Organizational Research, Entrepreneurship: Theory \& Practice, 27(4), 401-416.

Fama, E. F. and Jensen, M. C. (1983) Separation of Ownership and Control, Journal of Law and Economics, 26, 301-325.

Feltham, T. S., Feltham, G. and Barnett, J. J. (2005) The Dependence of Family Businesses on a Single Decision-Maker, Journal of Small Business Management, 43(1), 1-15.

Fiegener, M. K., Brown, B. M., Dreux, D. R. and Dennis, W. J. (2000) The Adoption of Outside Boards by Small Private US Firms, Entrepreneurship \& Regional Development, 12, 291-309.

Finkelstein, S. and Hambrick, D. C. (1996) Strategic Leadership: Top Executives and Their Effects on Organizations. Minneapolis / St. Paul: West Publishing Company.

Forbes, D. P. (2005) Are Some Entrepreneurs More Overconfident Than Others?, Journal of Business Venturing, 20(5), 623-640.

Forbes, D. P. and Milliken, F. J. (1999) Cognition and Corporate Governance: Understanding Boards of Directors as Strategic Decision-Making Groups, Academy of Management Review, 24(3), 489-506.

Ford, R. H. (1988) Outside Directors and the Privately-Owned Firm: Are They Necessary?, Entrepreneurship: Theory \& Practice, 13(1), 49-57.

Fox, H. W. (1982) Quasi-Boards: Useful Small Business Confidants, Harvard Business Review, 60(1), 158-165.

Fox, H. W. (1983) Quasi-Boards: When a Company Needs Help, These Behind-the-Scenes Advisors Give Strong Support to Top Management, Management Review, 72(6), 4953.

Fox, H. W. (1984) Quasi-Boards - Guidance without Governance, American Journal of Small Business, 9(1), 12-18.

Fried, V., Bruton, G. D. and Hisrich, R. D. (1998) Strategy and the Board of Directors in Venture Capital-Backed Firms, Journal of Business Venturing, 13(6), 493-503.

Gabrielsson, J. and Huse, M. (2002) The Venture Capitalist and the Board of Directors in Smes: Roles and Processes, Venture Capital, 4(2), 125-146.

Gabrielsson, J. and Huse, M. (2005) "Outside" Directors in Sme Boards: A Call for Theoretical Reflections, Corporate Board: role, duties \& composition, 1(1), 28-38.

Gabrielsson, J. and Winlund, H. (2000) Boards of Directors in Small and Medium-Sized Industrial Firms: Examining the Effects of the Board's Working Style on Board Task Performance, Entrepreneurship \& Regional Development, 12(4), 311-330.

George, G., Wood Jr., R. D. and Khan, R. (2001) Networking Strategy of Boards: Implications for Small and Medium-Sized Enterprises, Entrepreneurship \& Regional Development, 13(3), 269-285.

Golden, B. R. and Zajac, E. J. (2001) When Will Boards Influence Strategy? Inclination X Power $=$ Strategic Change, Strategic Management Journal, 22(12), 1087-1111.

Gorman, M. and Sahlman, W. (1989) What Do Venture Capitalists Do?, Journal of Business Venturing, 4, 231-248. 
Graafland, J., Van de Ven, B., Stoffele, N. (2003) Strategies and Instruments for Organising CSR by Small and Large Businesses in the Netherlands, Journal of Business Ethics, 47, 45-60.

Grundei, J. and Talaulicar, T. (2002) Company Law and Corporate Governance of Start-Ups in Germany: Legal Stipulations, Managerial Requirements, and Modification Strategies, Journal of Management and Governance, 6(1), 1-27.

Hair, J. F. J., Anderson, R. E., Tatham, R. L. and Black, W. C. (1998) Multivariate Data Analysis. Upper Saddle River: Prentice-Hall Inc.

Hambrick, D. C. and Finkelstein, S. (1987) Managerial Discretion: A Bridge between Polar Views of Organizational Outcomes. Greenwich: CT: JAI Press, 369-406.

Handler, W. C. (1989) Methodological Issues and Considerations in Studying Family Businesses, Family Business Review, 2(3), 257-276.

Harris, D., Martinez, J. I. and Ward, J. L. (1994) Is Strategy Different for the Family-Owned Business?, Family Business Review, 7(2), 159-175.

Hillman, A. J., Cannella, A. A. J. and Paetzold, R. L. (2000) The Resource Dependence Role of Corporate Directors: Strategic Adaptation of Board Composition in Response to Environmental Change, Journal of Management Studies, 37(2), 235-255.

Hillman, A. J. and Dalziel, T. (2003) Boards of Directors and Firm Performance: Integrating Agency and Resource Dependence Perspectives, Academy of Management Review, 28(3), 383-396.

Hitt, M. A., Hoskisson, R. E., Johnson, R. A. and Moesel, D. D. (1996) The Market for Corporate Control and Firm Innovation. Academy of Management Journal, 39(5), 1084-1119.

Hung, H. (1998) A Typology of the Theories of the Roles of Governing Boards, Corporate Governance: An International Review, 6(2), 101-111.

Huse, M. (1990) Board Composition in Small Enterprises, Entrepreneurship \& Regional Development, 2, 363-373.

Huse, M. (1993) Relational Norms as a Supplement to Neo-Classical Understanding of Directorates: An Empirical Study of Boards of Directors, Journal of SocioEconomics, 22(3), 219-241.

Huse, M. (1994) Board-Management Relations in Small Firms: The Paradox of Simultaneous Independence and Interdependence, Small Business Economics, 6, 55-72.

Huse, M. (1995) Tante, Barbar eller Klan:om Styrets rolle (in Norwegian: Aunt, Barbarian or Clan - About the Board's Role). Bergen: Fagbokförlaget.

Huse, M. (1998) Researching the Dynamics of Board-Stakeholder Relations, Long Range Planning, 31(2), 218-226.

Huse, M. (2000) Boards of Directors in SMEs: A Review and Research Agenda, Entrepreneurship \& Regional Development, 12, 271-290.

Huse, M. (2005a) Accountability and Creating Accountability: A Framework for Exploring Behavioural Perspectives of Corporate Governance, British Journal of Management, $16,65-79$.

Huse, M. (2005b) Corporate Governance: Understanding Important Contingencies, Corporate Ownership \& Control, 2(4), 41-50.

Jain, S. K. and Gumpert, D. E. (1980) Look to Outsiders to Strengthen Small Business Boards, Harvard Business Review, 58(4), 162-170.

Jensen, M. C. and Meckling, W. H. (1976) Theory of the Firm: Managerial Behavior, Agency Costs and Ownership Structure, Journal of Financial Economics, 3, 305-360.

Johannisson, B. and Huse, M. (2000) Recruiting Outside Board Members in the Small Family Business: An Ideological Challenge, Entrepreneurship \& Regional Development, 12, 353-378.

Johnson, J. L., Daily, C. M. and Ellstrand, A. E. (1996) Boards of Directors: A Review and Research Agenda, Journal of Management, 22(3), 409-438. 
Judge, W. and Zeithaml, C. (1992) Institutional and Strategic Choice Perspectives on Board Involvement in the Strategic Decision Process, Academy of Management Journal, 35, 766-794.

Kaiser, H. F. (1970) A Second-Generation Little Jiffy, Psychometrika, 35, 401-415.

Kaiser, H. F. (1974) Little Jiffy, Mark Iv, Educational and Psychology Measurement, 34, 111117.

Kelly, L. M., Athanassiou, N. and Crittenden, W. F. (2000) Founder Centrality and Strategic Behavior in the Family-Owned Firm, Entrepreneurship: Theory \& Practice, 25(2), 2742.

Kim, J.-O. and Mueller, C. W. (1978) Factor Analysis: Statistical Methods and Practical Issues. Beverly Hills: Sage Publications.

Lannoo, K. (1999) A European Perspective on Corporate Governance, Journal of Common Market Studies, 37(2), 269-294.

Lipton, M. and Lorsch, J. W. (1992) A Modest Proposal for Improved Corporate Governance, The Business Lawyer, 48, 58-79.

Lubatkin, M. H., Schulze, W. S., Ling, Y. and Dino, R. N. (2005) The Effects of Parental Altruism on the Governance of Family-Managed Firms, Journal of Organizational Behavior, 26(3), 313-330.

Lynall, M. D., Golden, B. R. and Hillman, A. J. (2003) Board Composition from Adolescence to Maturity: A Multitheoretic View, Academy of Management Review, 28(3), 416431.

Mace, M. L. (1948) The Board of Directors in Small Corporations, Boston MA: Graduate School of Business Administration, Harvard University Press, Unpublished Ph.D. dissertation.

Mace, M. L. (1971) Directors: Myth and Reality. Boston: Division of Research, Graduate School of Business Administration, Harvard University.

Markman, G. D., Balkin, D. B. and Schjoedt, L. (2001) Governing the Innovation Process in Entrepreneurial Firms, Journal of High Technology Management Research, 12, 273293.

McNulty, T. and Pettigrew, A. M. (1999) Strategists on the Board, Organization Studies, 20(1), 47-74.

Moerland, P. W. (1995). Alternative Disciplinary Mechanisms in Different Corporate Systems. Journal of Economic Behavior and Organization, 16, 17-34.

Mustakallio, M., Autio, E. and Zahra, S. A. (2002) Relational and Contractual Governance in Family Firms: Effects on Strategic Decision Making, Family Business Review, 15(3), 205-222.

Nash, J. M. (1988) Boards of Privately Held Companies: Their Responsibilities and Structure, Family Business Review, 1(3), 263-270.

Neubauer, F. and Lank, A. G. (1998) The Family Business: Its Governance for Sustainability. London: McMillan Business.

Pearce, J. A. and Zahra, S. A. (1991) The Relative Power of CEOs and Boards of Directors: Associations with Corporate Performance, Stategic Management Journal, 12(2), 135153.

Pearce, J. A. and Zahra, S. A. (1992) Board Composition from a Strategic Contingency Perspective, Journal of Management Studies, 29(4), 411-438.

Pettigrew, A. M. (1992) On Studying Managerial Elites, Strategic Management Journal, 13, 163-182.

Pfeffer, J. and Salancik, G. R. (1978) The External Control of Organizations. New York: Harper \& Row.

Robinson, J. P., Shaver, P. R. and Wrightsman, L. S. (1991) Criteria for Scale Selection and Evaluation. San Diego, California: Academic Press.

Rosenstein, J. (1988) The Board and Strategy: Venture Capital and High Technology, Journal of Business Venturing, 3, 159-170. 
Sadler-Smith, E. (2004) Cognitive Style and the Management of Small and Medium-Sized Enterprises, Organization Studies, 25(2), 155-182.

Schipani, C. A. and Siedel, G. J. (1988) Legal Liability: The Board of Directors, Family Business Review, 4(3), 269-285.

Schulze, W. S., Lubatkin, M. H., Dino, R. N. and Buchholtz, A. K. (2001) Agency Relationships in Family Firms: Theory and Evidence, Organization Science, 12(2), 99-116.

Schwartz, M. A. and Barnes, L. B. (1991) Outside Boards and Family Businesses: Another Look, Family Business Review, 4(3), 269-285.

Shanker, M. C. and Astrachan, J. H. (1996) Myths and Realities: Family Businesses' Contribution to the Us Economy - a Framework for Assessing Family Business Statistics, Family Business Review, 9(2), 107-119.

Simon, M., Houghton, S. M. and Aquino, K. (2000) Cognitive Biases, Risk Perception, and Venture Formation: How Individuals Decide to Start Companies, Journal of Business Venturing, 15(2), 113-134.

Steier, L. P., Chrisman, J. J. and Chua, J. H. (2004) Entrepreneurial Management and Governance in Family Firms: An Introduction, Entrepreneurship: Theory \& Practice, 28(4), 295-303.

Stevens, J. P. (1992) Applied Multivariate Statistics for the Social Sciences. Hillsdale: NJ: Erlbaum.

Stiles, P. (2001) The Impact of the Board on Strategy: An Empirical Examination, Journal of Management Studies, 38(5), 627-650.

Van den Berghe, L. A. A. and Carchon, S. (2002) Corporate Governance Practices in Flemish Family Businesses, Corporate Governance: An International Review, 10(3), 225-245.

Ward, J. (1992) Creating Effective Boards for Private Enterprises. San Francisco: JosseyBass.

Ward, J. and Handy, J. L. (1988) A Survey of Board Practices, Family Business Review, 1(3), 289-308.

Weimer, J. and J. C. Pape (1999). A Taxonomy of Systems of Corporate Governance. Corporate Governance, 7(2), 152-166.

Wernerfelt, B. (1984) A Resource-Based View of the Firm, Strategic Management Journal, 5, 171-180.

Westhead, P. and Cowling, M. (1998) Family Firm Research: The Need for a Methodological Rethink, Entrepreneurship: Theory and Practice, 23(1), 31-56.

Westhead, P., Howorth, C. and Cowling, M. (2002) Ownership and Management Issues in First Generation and Multi-Generation Family Firms, Entrepreneurship \& Regional Development, 14, 247-269.

Westphal, J. D. (1998) Board Games: How CEOs Adapt to Increases in Structural Board Independence from Management, Administrative Science Quarterly, 43, 511-537.

Westphal, J. D. (1999) Collaboration in the Board room: Behavioral and Performance Consequences of CEO-Board Social Ties. Academy of Management Journal, 42(1), 7-24.

Whisler, T. L. (1988) The Role of the Board in the Threshold Firm, Family Business Review, 1(3), 309-312.

Zahra, S. A. and Filatotchev, I. (2004) Governance of the Entrepreneurial Treshold Firm: A Knowledge-Based Perspective, Journal of Management Studies, 41(5), 885-897.

Zahra, S. A. and Pearce, J. A. (1989) Boards of Directors and Corporate Financial Performance: A Review and Integrative Model, Journal of Management, 15(2), 291334. 


\section{Table 1: Board role definitions}

\begin{tabular}{|c|c|c|c|c|c|}
\hline & $\begin{array}{c}\text { Pearce \& Zahra } 1992 \\
(\text { p.412-13) }\end{array}$ & $\begin{array}{c}\text { Finkelstein \& } \\
\text { Hambrick 1996 } \\
\text { (p.210) } \\
\end{array}$ & $\begin{array}{c}\text { Johnson, Daily \& Ellstrand } 1996 \\
\text { (p.410) }\end{array}$ & $\begin{array}{c}\text { Hillman, Cannella \& } \\
\text { Paetzold } 2000 \\
\text { (p.236) }\end{array}$ & $\begin{array}{c}\text { Hillman \& Dalziel } 2003 \\
\text { (p.384-88) }\end{array}$ \\
\hline Control role & $\begin{array}{l}\text { 'the selection of senior } \\
\text { executives }(9) \text {; monitoring, } \\
\text { evaluating and rewarding executive } \\
\text { performance(7); and using board } \\
\text { power to protect shareholders' } \\
\text { interests }(6)^{\prime}\end{array}$ & $\begin{array}{l}\text { 'they play a role in } \\
\text { administration and } \\
\text { internal control } \\
(4,6,7,8,9,10)^{\prime} \text { (labelled } \\
\text { as the first role) }\end{array}$ & $\begin{array}{l}\text { 'entailing directors monitoring } \\
\text { managers as fiduciaries of } \\
\text { stockholders' }(6) \text {, which includes } \\
\text { 'hiring and firing the CEO }(4,9), \ldots \\
\text { determining executive pay }(8), \text { and } \\
\ldots \text { monitoring managers' }(6,7,10)\end{array}$ & $\begin{array}{l}\text { 'serve shareholders(6) by } \\
\text { ratifying the decisions of } \\
\text { managers and monitoring } \\
\text { the implementation of } \\
\text { those decisions'(7) }\end{array}$ & $\begin{array}{l}\text { 'Monitoring the CEO(7), monitoring strategy } \\
\text { implementation(5), planning CEO succession(4), and } \\
\text { evaluating and rewarding the CEO/top managers }(8) \text { ' (also } \\
\text { labelled 'monitoring function') }\end{array}$ \\
\hline$\underline{\text { Strategic role }}$ & $\begin{array}{l}\text { 'includes directors' involvement in } \\
\text { defining the firm's business } \\
\text { concept, developing a company's } \\
\text { mission, and selecting and } \\
\text { implementing a company } \\
\text { strategy }(2,5)^{\prime}\end{array}$ & - & - & - & - \\
\hline Service role & $\begin{array}{l}\text { 'representing the firms' interest in } \\
\text { the community(1), linking the firm } \\
\text { with its external environment } \\
(1,3,11) \text { and performing ceremonial } \\
\text { functions in the life of the } \\
\text { firm }(1,11)^{\prime}\end{array}$ & \multirow{2}{*}{$\begin{array}{l}\text { 'act as buffers and } \\
\text { boundary spanners, } \\
\text { linking organizations to } \\
\text { critical resources in the } \\
\text { environment( }(3) \text { and to } \\
\text { valuable information } \\
\text { residing in a } \\
\text { network(11)' (labelled } \\
\text { as the second role) }\end{array}$} & $\begin{array}{l}\text { 'advising the CEO and top } \\
\text { managers(2)... initiating and } \\
\text { formulating strategy }(5)^{\prime}\end{array}$ & - & - \\
\hline $\begin{array}{l}\text { Resource } \\
\text { dependence role }\end{array}$ & - & & $\begin{array}{l}\text { 'facilitating the acquisition of } \\
\text { resources critical to the firm's } \\
\text { success(3)... a legitimising } \\
\text { function(1)' }\end{array}$ & $\begin{array}{l}\text { 'to connect the firm with } \\
\text { external factors which } \\
\text { generate uncertainty and } \\
\text { external } \\
\text { dependencies(11)...bring } \\
\text { resources to the firm(3)' }\end{array}$ & $\begin{array}{l}\text { 'providing legitimacy/bolstering the public image of the } \\
\text { firm(1), providing expertise,... administering advice and } \\
\text { counsel(2), linking the firm to important stakeholders or } \\
\text { other important entities(11), facilitation of access to } \\
\text { resources(3), building external relationships(11), and aiding } \\
\text { in the formulation of strategy or other important firm } \\
\text { decisions(5)' (also labelled 'provision of resources } \\
\text { function') }\end{array}$ \\
\hline
\end{tabular}

The numbers included between brackets correspond to the variables (e.g. 1 = task_1) displayed in table 4. They indicate the variables' descent and display the coverage of the general board role definitions by the 11 specific tasks measured in this study. 


\section{Table 2: Literature Overview: Board Roles in SMEs and Family Businesses}

\begin{tabular}{|c|c|c|c|}
\hline Author(s) and Year & Research Characteristics & \begin{tabular}{|l|} 
Theoretical Basis \\
\end{tabular} & Board Role or Tasks Research Findings \\
\hline $\begin{array}{l}\text { Barach } \\
1984\end{array}$ & $\begin{array}{l}\text { Family Firms } \\
\text { Anecdotic-Prescriptive } \\
\text { No empirical data }\end{array}$ & $\begin{array}{l}\text { The theory of the family of } \\
\text { enterprises }\end{array}$ & $\begin{array}{cl}\text { Important Tasks: } \\
- & \text { restructuring the entire company in order to save it. } \\
- & \text { resolving conflict. }\end{array}$ \\
\hline $\begin{array}{l}\text { Borch \& Huse } \\
1993\end{array}$ & $\begin{array}{l}\text { SME } \\
\text { Empirical research - survey } \\
\text { CEO (115) and board chairperson (80) } \\
\text { Hotels in Norway and Sweden }\end{array}$ & Network theory & $\begin{array}{l}\text { Measuring the degree of board's networking involvement. } \\
\text { Authors stress importance of board's networking function of contacting and } \\
\text { lobbying. } \\
\text { Role in creating, maintaining, and influencing external contacts of importance to } \\
\text { the firm. }\end{array}$ \\
\hline $\begin{array}{l}\text { Castaldi \& Wortman } \\
1984\end{array}$ & $\begin{array}{l}\text { Small corporations } \\
\text { Anecdotic - Prescriptive } \\
\text { No empirical data }\end{array}$ & $\begin{array}{l}\text { Do not directly refer to, but indirectly } \\
\text { take a resource-based perspective. }\end{array}$ & $\begin{array}{l}\text { List of } 12 \text { general functions/responsibilities of the board of directors that have to } \\
\text { be established and tailor-made to fit individual corporations, depending on the } \\
\text { organization and the composition of the board of directors. }\end{array}$ \\
\hline $\begin{array}{l}\text { Corbetta \& Tomaselli } \\
1996\end{array}$ & $\begin{array}{l}\text { Family Firms } \\
\text { Empirical research - survey } \\
\text { Chairman of the board (often CEO) } \\
73 \text { Italian family businesses }\end{array}$ & $\begin{array}{l}\text { No specific theoretical basis. } \\
\text { Pragmatic view on the relative time } \\
\text { boards devote to certain tasks. }\end{array}$ & $\begin{array}{l}\text { Task performance: } \\
-\quad \text { listening to reports or papers } \\
-\quad \text { approving decisions } \\
-\quad \text { discussing crucial points } \\
\text { Tasks mainly focused on strategic variables. }\end{array}$ \\
\hline $\begin{array}{l}\text { Davis \& Pett } \\
2000\end{array}$ & $\begin{array}{l}\text { Family Businesses/SME } \\
\text { Empirical research - survey } \\
\text { Owner/president } \\
614 \text { US-based family owned SMEs } \\
\end{array}$ & Resource dependency & 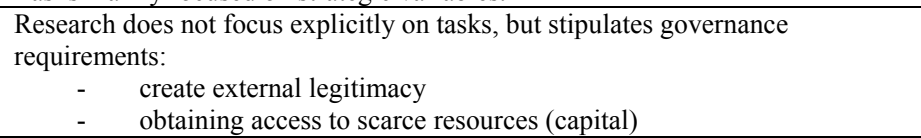 \\
\hline $\begin{array}{l}\text { Deakins, O’Neil \& Mileham } \\
2000\end{array}$ & $\begin{array}{l}\text { Small entrepreneurial companies } \\
\text { Empirical research - interviews } \\
46 \text { Scottish CEOs }\end{array}$ & $\begin{array}{l}\text { Resource dependency } \\
\text { Agency theory }\end{array}$ & $\begin{array}{l}\text { Analysis of } 18 \text { actions/roles undertaken by external directors in } \mathrm{VC} \text { and non-VC } \\
\text { funded companies. Grouped by the author in different roles: provide experience } \\
\text { and advice, strategic planning/advice and monitoring. Less importance for } \\
\text { networking role. }\end{array}$ \\
\hline $\begin{array}{l}\text { Fiegener, Brown, Dreux \& Dennis } \\
2000\end{array}$ & $\begin{array}{l}\text { Small private firms } \\
\text { Empirical research - survey } \\
\text { CEO } \\
3070 \text { Us-based respondents }\end{array}$ & $\begin{array}{l}\text { No explicit theory indicated, but } \\
\text { reference to service, resource and } \\
\text { monitoring role identified in earlier } \\
\text { research }\end{array}$ & $\begin{array}{l}\text { Focus on reasons to adopt outside boards: } \\
\text { 1) To satisfy external owners } \\
\text { 2) For the service and resource benefits outsiders provide }\end{array}$ \\
\hline $\begin{array}{l}\text { Ford } \\
1988\end{array}$ & $\begin{array}{l}\text { Privately-owned entrepreneurial firms (Inc. } \\
500 \text { ) } \\
\text { Empirical research - survey and interviews } \\
352 \text { CEO's and } 124 \text { Board members from } 35 \\
\text { companies }\end{array}$ & - & $\begin{array}{l}\text { Tests the influence of outside directors, thereby formulating } 12 \text { possible functions } \\
\text { or activities traditionally believed to be in the board's domain }\end{array}$ \\
\hline $\begin{array}{l}\text { Fox } \\
1982,1983,1984\end{array}$ & $\begin{array}{l}\text { Small businesses } \\
\text { Anecdotic - Prescriptive } \\
\text { One case study }\end{array}$ & $\begin{array}{l}\text { No specific theoretical basis. } \\
\text { Indirectly leaving from resource- } \\
\text { based view, regarding the } \\
\text { (quasi)board as a resource to the firm }\end{array}$ & $\begin{array}{l}\text { A variety task for quasi-boards (advisory council) are stipulated, which the author } \\
\text { groups in: } \\
\text { - helping with strategies and functional policies } \\
\text { - delve into operations } \\
\text { - mediate quarrels among owners and executives } \\
\text { The most delicate subject concerns managerial succession. }\end{array}$ \\
\hline
\end{tabular}


Table 2: continued

\begin{tabular}{|c|c|c|c|}
\hline Author(s) and Year & Research Characteristics & Theoretical Basis & Board Role or Tasks Research Findings \\
\hline $\begin{array}{l}\text { Gabrielsson and Huse } \\
2002\end{array}$ & $\begin{array}{l}\text { SMEs } \\
\text { Empirical research - survey, interviews and } \\
\text { cases } \\
\text { Different respondents } \\
\text { Four different Swedish samples }\end{array}$ & $\begin{array}{l}\text { Agency theory } \\
\text { Resource-based theory }\end{array}$ & $\begin{array}{l}\text { Examines } 16 \text { possible contributions of VC directors on boards, as well as the } \\
\text { most important tasks of the board. Nine board tasks are evaluated by VCs and } \\
\text { CEO's, and both perceive revising and formulating the firm's long-term strategy } \\
\text { as most important. }\end{array}$ \\
\hline $\begin{array}{l}\text { Gabrielsson and Huse } \\
2005\end{array}$ & $\begin{array}{l}\text { SMEs/Family Firms } \\
\text { Empirical research - Analysis from } 52 \\
\text { student research reports } \\
\text { Norwegian and Swedish SMEs and family } \\
\text { firms }\end{array}$ & $\begin{array}{l}\text { Agency theory } \\
\text { Resource-based view } \\
\text { Resource dependence theory }\end{array}$ & $\begin{array}{l}\text { Focus on roles and contributions of outside directors in different types of SMEs. } \\
\text { Indicate that different roles are related to theories used and specific ownership } \\
\text { structure studied. }\end{array}$ \\
\hline $\begin{array}{l}\text { Gabrielsson and Winlund } \\
2000\end{array}$ & $\begin{array}{l}\text { SMEs } \\
\text { Empirical research - survey } \\
\text { CEO's of } 302 \text { industrial SMEs in Sweden }\end{array}$ & $\begin{array}{l}\text { Agency theory } \\
\text { Resource-based view } \\
\text { Resource dependence theory }\end{array}$ & $\begin{array}{l}\text { Authors examine board task performance for two tasks: control and service. } \\
\text { Control measured on 10-item scale (based on work Fama and Jensen, 1983), } \\
\text { service measured on a seven-item scale (including items from Borch and Huse, } \\
1993 \text { and Huse, 1995) }\end{array}$ \\
\hline $\begin{array}{l}\text { George, Wood Jr. \& Khan } \\
2001\end{array}$ & $\begin{array}{l}\text { SME } \\
\text { Empirical research - interviews and survey } \\
\text { CEO's of } 70 \text { small US-based community } \\
\text { banks }\end{array}$ & $\begin{array}{l}\text { Resource dependency theory } \\
\text { Social network theory }\end{array}$ & $\begin{array}{l}\text { Board activity measured by seven-item scale. Items are based on interviews with } \\
\text { CEO's. Factor analysis of items results in two types of activities: functional and } \\
\text { relational. Besides, networking strategy of board measured, using four-item } \\
\text { scale, resulting from social network theory. }\end{array}$ \\
\hline $\begin{array}{l}\text { Graafland, Van de Ven \& Stoffele } \\
2003\end{array}$ & $\begin{array}{l}\text { SME/Family Firm } \\
\text { Empirical research - survey } \\
63 \text { Dutch SMEs }\end{array}$ & - & $\begin{array}{l}\text { Focus on CSR strategies and instrument. } \\
\text { Refers to board's task of being answerable for ethical questions. }\end{array}$ \\
\hline $\begin{array}{l}\text { Grundei and Talaulicar } \\
2002\end{array}$ & $\begin{array}{l}\text { Start-up companies } \\
\text { Empirical research - survey } \\
62 \text { German start-ups }\end{array}$ & Legalistic perspective & $\begin{array}{l}\text { Investigates three roles of supervisory boards: monitoring, counsel and liaison. } \\
\text { Most boards do not perform all three roles. No measurement items included. }\end{array}$ \\
\hline $\begin{array}{l}\text { Huse } \\
1990\end{array}$ & $\begin{array}{l}\text { SME } \\
\text { Empirical research - results of } 3 \text { studies ( } 2 x \\
\text { surveys, } 1 \mathrm{x} \text { case study) } \\
\text { I: } 92 \text { hotels (joint stock companies) } \\
\text { II: } 69 \text { CEOs from four industries } \\
\text { III: } 11 \text { CEOs, structured interviews + } \\
\text { secondary information }\end{array}$ & $\begin{array}{l}\text { Focus on: } \\
\text { Strategic leadership theory } \\
\text { (strategic involvement) } \\
\text { Resource dependence theory } \\
\text { Resource-based theory } \\
\text { (both: service/advisory role) } \\
\text { Reference to: } \\
\text { Agency theory (control role) }\end{array}$ & $\begin{array}{l}\text { Study II\&III include board functions. Results indicate that: } \\
\text { Study II: } \\
\text { Industry, family ownership, and director's ownership interests influence the } \\
\text { board's strategic involvement. } \\
\text { Study III: } \\
\text { Board size and number of insiders on the board are negatively correlated with } \\
\text { the board's involvement in mission development. } \\
\text { Board size is negatively correlated with the board's involvement as counselors } \\
\text { for the CEO. }\end{array}$ \\
\hline $\begin{array}{l}\text { Huse } \\
1993\end{array}$ & $\begin{array}{l}\text { SME } \\
\text { Empirical research - survey and telephone } \\
\text { interview } \\
118 \text { CEO's and } 88 \text { chairman of } 108 \text { hotels in } \\
\text { Norway and Sweden }\end{array}$ & $\begin{array}{l}\text { Stakeholder approach } \\
\text { Relational exchange theory } \\
\text { Agency theory }\end{array}$ & $\begin{array}{l}\text { Measurement of board's control and service task. Service measured by four } \\
\text { questions, control by eight questions. No literature references to how these } \\
\text { questions were selected. }\end{array}$ \\
\hline $\begin{array}{l}\text { Huse } \\
1994\end{array}$ & $\begin{array}{l}\text { Small Firms } \\
\text { Conceptual model development (empirical for } \\
\text { in(inter)dependence) }\end{array}$ & $\begin{array}{l}\text { Agency theory } \\
\text { Theory of contractual relations }\end{array}$ & $\begin{array}{l}\text { Focus on independence- interdependence relationship. } \\
\text { Reference to board's monitoring performance. }\end{array}$ \\
\hline
\end{tabular}




\section{Table 2: continued}

\begin{tabular}{|c|c|c|c|}
\hline Author(s) and Year & Research Characteristics & Theoretical Basis & Board Role or Tasks Research Findings \\
\hline $\begin{array}{l}\text { Huse } \\
1998\end{array}$ & $\begin{array}{l}\text { SME } \\
\text { Empirical research - cases } \\
3 \text { Norwegian SMEs }\end{array}$ & 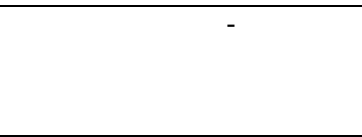 & $\begin{array}{l}\text { Identifies several sub-roles, which are group in three main roles: legitimizing, } \\
\text { advising and monitoring. Emphasizes that board roles may be influenced by } \\
\text { changes in the company and the environment, and by the stakes and the power of } \\
\text { the external and internal stakeholders. }\end{array}$ \\
\hline $\begin{array}{l}\text { Huse } \\
2000\end{array}$ & $\begin{array}{l}\text { SME } \\
\text { Conceptual model development }\end{array}$ & Reference to different theories & $\begin{array}{l}\text { Summary of different roles identified in the literature so far, based on general } \\
\text { management and SME literature. No measurement items included. }\end{array}$ \\
\hline $\begin{array}{l}\text { Huse } \\
2005 b\end{array}$ & $\begin{array}{l}\text { SME } \\
\text { Conceptual model development }\end{array}$ & Reference to different theories & $\begin{array}{l}\text { Indicates that the board's external control role and the board's internal service } \\
\text { role can each be split in three sub-roles: output control, behavioural control and } \\
\text { strategic control for the control role, networking, advise and strategic leadership } \\
\text { for the service role. }\end{array}$ \\
\hline $\begin{array}{l}\text { Jain } \\
1980\end{array}$ & $\begin{array}{l}\text { Small companies } \\
\text { Anecdotic - no empirical research }\end{array}$ & - & $\begin{array}{l}\text { Board members have to provide expertise to compensate for small companies' } \\
\text { managerial deficiencies. }\end{array}$ \\
\hline $\begin{array}{l}\text { Johannisson \& Huse } \\
2000\end{array}$ & $\begin{array}{l}\text { Small family business } \\
\text { Empirical research }- \text { cases and in-depth } \\
\text { interviews } \\
\text { CEO and a board member } \\
12+2 \text { Swedish family businesses }\end{array}$ & $\begin{array}{l}\text { Agency theory } \\
\text { Resource-based view } \\
\text { Resource dependence theory } \\
\text { Managerial hegemony }\end{array}$ & $\begin{array}{l}\text { Several functions the boards perform are indicated: monitoring, providing } \\
\text { advice, legitimation, networking, disciplining. }\end{array}$ \\
\hline $\begin{array}{l}\text { Markman, Balkin \& Schjoedt } \\
2001\end{array}$ & $\begin{array}{l}\text { Entrepreneurial firms } \\
\text { Conceptual model development }\end{array}$ & Agency theory & $\begin{array}{l}\text { Stress the importance of the board's monitoring function within the firm's } \\
\text { innovation process. }\end{array}$ \\
\hline $\begin{array}{l}\text { Mustakallio, Autio \& Zahra } \\
2002\end{array}$ & $\begin{array}{l}\text { Family Firms } \\
\text { Empirical research }- \text { survey } \\
\text { Board chairman or CEO } \\
192 \text { Finnish family businesses }\end{array}$ & $\begin{array}{l}\text { Agency theory } \\
\text { Social capital theory }\end{array}$ & $\begin{array}{l}\text { Performance of two board functions is measured: monitoring and counsel. } \\
\text { Monitoring measured with five-item scale (Hitt et al. 1996, Westphal, 1999). } \\
\text { Councel measured on five-item scale (Pearce and Zahra 1991, Zahra and Pearce } \\
\text { 1989, Westphal 1999) }\end{array}$ \\
\hline $\begin{array}{l}\text { Nash } \\
1988\end{array}$ & $\begin{array}{l}\text { Privately held companies } \\
\text { Anecdotic / prescriptive, from the president } \\
\text { of the National Association of Corporate } \\
\text { Directors point of view. }\end{array}$ & - & $\begin{array}{l}\text { Presents a vision and advice to privately held firms on several board related } \\
\text { issues such as the board's legal requirement, the board's role and composition, } \\
\text { use of committees, the role of the chairman, information flow, board meetings } \\
\text { (minutes), advisory boards, and what are attributes of a good director. }\end{array}$ \\
\hline $\begin{array}{l}\text { Neubauer and Lank } \\
1998\end{array}$ & $\begin{array}{l}\text { Family business } \\
\text { Conceptual } \\
\text { Mainly written for practitioners' audience. }\end{array}$ & - & $\begin{array}{l}\text { Conceptualization and description of the system and processes of governance in } \\
\text { family businesses in broad sense. Governance tasks: succession, vision \& } \\
\text { strategy, financial resources, control. }\end{array}$ \\
\hline $\begin{array}{l}\text { Rosenstein } \\
1988\end{array}$ & $\begin{array}{l}\text { Small high-technology firms operating with } \\
\text { venture capital funds } \\
\text { Exploratory research - interviews } \\
\text { Six Dallas-based venture capital firms }\end{array}$ & - & $\begin{array}{l}\text { Focus on board involvement. Indicates that these types of boards are actively } \\
\text { involved in strategy formulation and revision. }\end{array}$ \\
\hline $\begin{array}{l}\text { Schipani and Siedel } \\
1988\end{array}$ & $\begin{array}{l}\text { Family Businesses } \\
\text { Descriptive }\end{array}$ & Legalistic perspective & $\begin{array}{l}\text { Discusses the origins and meanings of four bases of director's legal liabilities: } \\
\text { duty of care, fiduciary duty, piercing the corporate veil, and liability for personal } \\
\text { action. }\end{array}$ \\
\hline
\end{tabular}


Table 2: continued

\begin{tabular}{|c|c|c|c|}
\hline Author(s) and Year & Research Characteristics & Theoretical Basis & Board Role or Tasks Research Findings \\
\hline $\begin{array}{l}\text { Schwartz \& Barnes } \\
1991\end{array}$ & $\begin{array}{l}\text { Family Businesses } \\
\text { Empirical research - survey } \\
262 \text { CEOs of US-based family-owned } \\
\text { businesses }\end{array}$ & 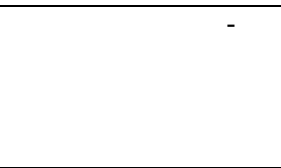 & $\begin{array}{l}\text { Discusses outside directors' areas of most help (unbiased, objective views, } \\
\text { accountability of management, network of contacts, asking challenging } \\
\text { questions, long-term perspective, setting executive salaries) and least help (day- } \\
\text { to-day operations, issues of family conflict, technical expertise, very specific } \\
\text { matters) }\end{array}$ \\
\hline $\begin{array}{l}\text { Van den Berghe \& Carchon } \\
2002\end{array}$ & $\begin{array}{l}\text { Family Businesses } \\
\text { Empirical research - survey } \\
\text { Director or President of the board } \\
\text { 325 Flemish family firms } \\
\end{array}$ & $\begin{array}{l}\text { Agency theory } \\
\text { Stakeholder theory }\end{array}$ & $\begin{array}{l}\text { Performance on five board tasks examined: (1) strategy formulation, (2) acting } \\
\text { as a sounding board for management, (3) supervision of management, (4) day-to- } \\
\text { day policy topics and ( } 50 \text { satisfying legal requirements. }\end{array}$ \\
\hline $\begin{array}{l}\text { Ward and Handy } \\
1988\end{array}$ & $\begin{array}{l}\text { Small private firms } \\
\text { Empirical research - survey } \\
\text { CEo's of } 147 \text { US-based firms }\end{array}$ & - & $\begin{array}{l}\text { Role of the outside board is mainly advice and council, and accountability. } \\
\text { Answers to open questions result in seven reasons to have an outside board. }\end{array}$ \\
\hline $\begin{array}{l}\text { Whisler } \\
1988\end{array}$ & $\begin{array}{l}\text { Family companies } \\
\text { Empirical research - method unknown } \\
\text { More than } 70 \text { threshold firms }\end{array}$ & - & $\begin{array}{l}\text { Three appropriate roles for outside directors in the threshold firm: (1) preceptor, } \\
\text { (2) technical adviser and (3) arbitrator. }\end{array}$ \\
\hline $\begin{array}{l}\text { Zahra \& Filatotchev } \\
2004\end{array}$ & $\begin{array}{l}\text { Young entrepreneurial threshold firms } \\
\text { Conceptual }\end{array}$ & Knowledge-based view & $\begin{array}{l}\text { Stipulate the importance and change of organizational learning and governance, } \\
\text { related to the organizational life cycle. Also discuss the interdependence between } \\
\text { organizational learning and governance. }\end{array}$ \\
\hline
\end{tabular}




\section{Table 3: Sample Characteristics}

\section{3a: Firm Characteristics}

\begin{tabular}{|c|c|c|c|c|c|c|c|}
\hline Characteristics & $\mathbf{N}$ & Mean & Median. & Min. & Max. & Std.dev. & Pct. \\
\hline \# Employees & 199 & 33 & 17 & 2 & 250 & 44.36 & \\
\hline \# Board members & 200 & 3.6 & 3 & 2 & 12 & 1.44 & \\
\hline $\begin{array}{r}\text { \# External board } \\
\text { members }\end{array}$ & 202 & 0.31 & 0 & 0 & 6 & 0.82 & $\begin{array}{r}17.8 \% \\
\geq 1 \text { ext. }\end{array}$ \\
\hline $\begin{array}{r}\text { Growth phase: Startup } \\
\text { Growth } \\
\text { Maturation } \\
\text { Decline }\end{array}$ & 197 & - & - & - & - & - & $\begin{array}{c}0 \% \\
37 \% \\
50 \% \\
13 \%\end{array}$ \\
\hline $\begin{array}{r}\text { Generation: } 1^{\text {st }} \\
2^{\text {nd }} \\
3^{\text {rd }} \\
\geq 4^{\text {th }}\end{array}$ & 200 & - & - & - & - & - & $\begin{array}{c}22 \% \\
51 \% \\
20 \% \\
7 \%\end{array}$ \\
\hline CEO duality & 189 & - & - & - & - & - & $76 \%$ \\
\hline
\end{tabular}

3b: Ownership Structure

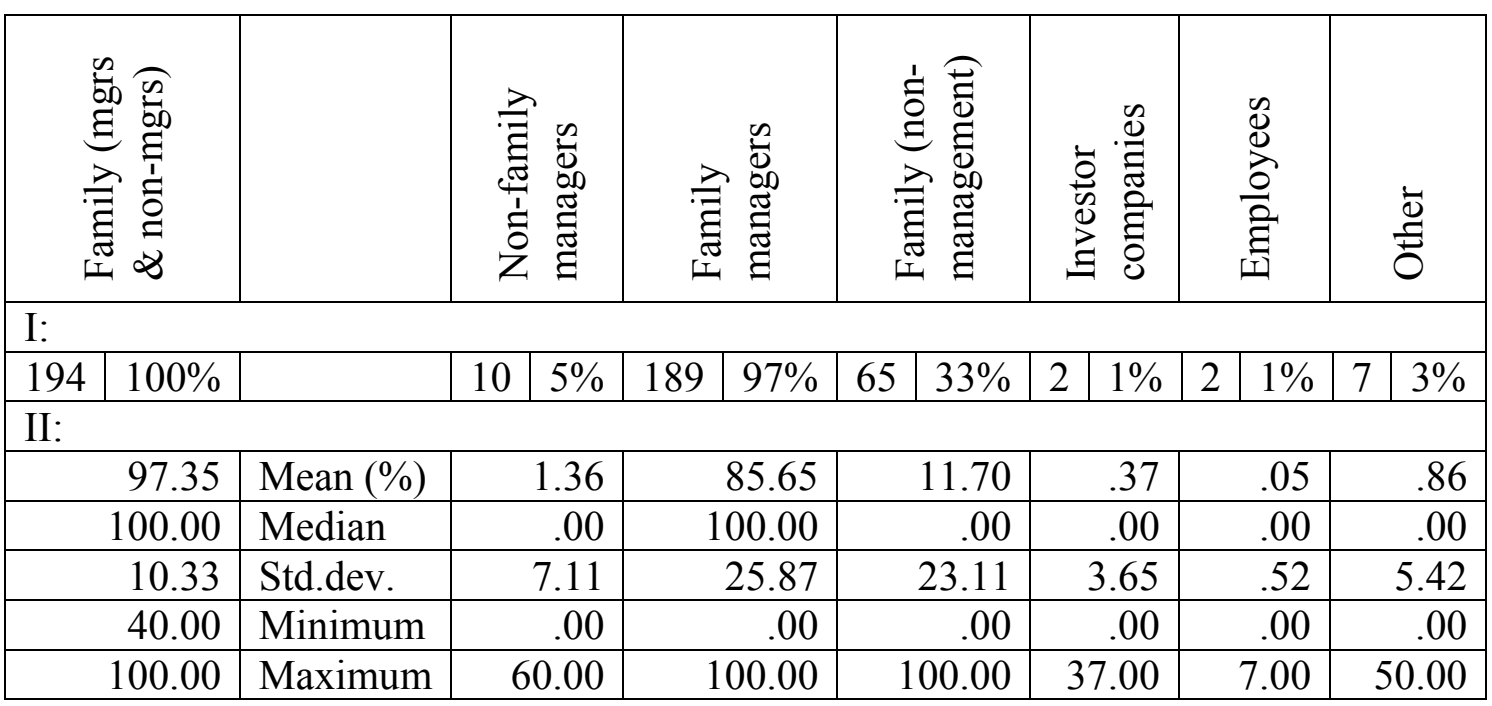

$\mathrm{N}=194$ (of 202 observations included in the principal components analysis, 194 disclose full information on their ownership structure).

I: Number and percentage of firms in sample $(\mathrm{N}=202)$ of which shares are (partly) owned by the ownership category.

II: Statistics for the ownership percentages according to the type of owner. 


\section{Table 4: Board task part of the questionnaire*}

In column 2 of the next table various possible tasks for a board of directors are stated. Indicate in the third column to what extent the board of directors of your company fulfils these tasks. Subsequently, indicate in the last column to what extent you find these tasks important for a board of directors.

\begin{tabular}{|c|c|c|c|}
\hline Label & Task & $\begin{array}{c}\text { Performance of } \\
\text { Board of } \\
\text { Directors } \\
\end{array}$ & $\begin{array}{c}\text { Importance } \\
\text { of these } \\
\text { tasks }^{* * *} \\
\end{array}$ \\
\hline task 1 & Building organizational reputation & $1-2-3-4-5$ & $1-2-3-4-5$ \\
\hline task 2 & Advising management & $1-2-3-4-5$ & $1-2-3-4-5$ \\
\hline task 3 & Taking care of access to extra resources & $1-2-3-4-5$ & $1-2-3-4-5$ \\
\hline task 4 & Direct succession problems & $1-2-3-4-5$ & $1-2-3-4-5$ \\
\hline task 5 & Formulate / ratify organizational strategy & $1-2-3-4-5$ & $1-2-3-4-5$ \\
\hline task 6 & Maximize shareholder value & $1-2-3-4-5$ & $1-2-3-4-5$ \\
\hline task 7 & Evaluate/control management & $1-2-3-4-5$ & $1-2-3-4-5$ \\
\hline task 8 & performance & $1-2-3-4-5$ & $1-2-3-4-5$ \\
\hline task 9 & Determine salary/compensation of mgt. & $1-2-3-4-5$ & $1-2-3-4-5$ \\
\hline task_10 & Select new managers & $1-2-3-4-5$ & $1-2-3-4-5$ \\
\hline task_11 & $\begin{array}{l}\text { Determine management's responsibility } \\
\text { Networking and maintain relations }\end{array}$ & $1-2-3-4-5$ & $1-2-3-4-5$ \\
\hline$*$ & \multicolumn{3}{|l|}{ Adapted from the questionnaire } \\
\hline $\begin{array}{l}* * \\
* * *\end{array}$ & \multicolumn{3}{|l|}{$1=$ bad, little attention, $5=$ very good score, suffi } \\
\hline
\end{tabular}




\section{Table 5: Board role performance in small and medium-sized family firms}

\begin{tabular}{|c|c|c|}
\hline & Control role & Service role \\
\hline Select new managers & .983 & -.301 \\
\hline Determine management's responsibility & .782 & .035 \\
\hline Determine salary/compensation of mgt. & $\overline{.708}$ & .075 \\
\hline Direct succession problems & .652 & .012 \\
\hline Maximise shareholder value & $\overline{.607}$ & .164 \\
\hline Evaluate/control mgt. performance & .495 & .369 \\
\hline Building organisational reputation & -.204 & .871 \\
\hline Networking and maintain relations & -.141 & .822 \\
\hline Advising management & .247 & $\overline{.605}$ \\
\hline Formulate/ratify organisational strategy & .214 &.$\overline{.559}$ \\
\hline Taking care of access to extra resources & .237 & .495 \\
\hline
\end{tabular}

$\mathrm{N}=202$ (using listwise exclusion)

The control role and the service role cumulatively explain $55.97 \%$ of the variance in the model.

Control role Cronbach's $\alpha=.83$ and service role Cronbach's $\alpha=.78$, both showing a meritorious level of internal consistency. 


\section{Table 6: Board roles in small and medium-sized family firms: average importance and performance}

\begin{tabular}{|c|c|c|c|c|c|}
\hline \multicolumn{3}{|c|}{ Control role } & \multicolumn{3}{|c|}{ Service role } \\
\hline$\underline{\text { Task }}$ & $\begin{array}{l}\frac{\text { Average }}{\underline{\text { task }}} \\
\text { importance } \\
\end{array}$ & $\begin{array}{c}\text { Average } \\
\text { board task } \\
\text { performance } \\
\end{array}$ & Task & $\begin{array}{l}\frac{\text { Average }}{\text { task }} \\
\text { importance } \\
\end{array}$ & $\begin{array}{c}\underline{\text { Average }} \\
\text { Board task } \\
\text { performance } \\
\end{array}$ \\
\hline & & & $\begin{array}{l}\text { Building } \\
\text { organisational } \\
\text { reputation }\end{array}$ & 4.01 & 3.60 \\
\hline & & & $\begin{array}{l}\text { Formulate/ratify } \\
\text { organisational } \\
\text { strategy }\end{array}$ & 3.86 & 3.37 \\
\hline & & & $\begin{array}{l}\text { Networking and } \\
\text { maintain } \\
\text { relations }\end{array}$ & 3.71 & 3.32 \\
\hline & & & $\begin{array}{l}\text { Advising } \\
\text { management }\end{array}$ & 3.65 & 3.29 \\
\hline $\begin{array}{l}\text { Direct succession } \\
\text { problems }\end{array}$ & 3.60 & 3.10 & & & \\
\hline \multirow[t]{2}{*}{$\begin{array}{l}\text { Evaluate/control } \\
\text { management } \\
\text { performance }\end{array}$} & 3.54 & 3.04 & & & \\
\hline & & & $\begin{array}{l}\text { Taking care of } \\
\text { access to extra } \\
\text { resources }\end{array}$ & 3.17 & 2.99 \\
\hline $\begin{array}{l}\text { Determine } \\
\text { management's } \\
\text { responsibility } \\
\end{array}$ & 3.25 & 2.97 & & & \\
\hline $\begin{array}{l}\text { Maximise shareholder } \\
\text { value }\end{array}$ & 3.16 & 2.82 & & & \\
\hline $\begin{array}{l}\text { Determine } \\
\text { salary/compensation } \\
\text { of management }\end{array}$ & 3.09 & 2.77 & & & \\
\hline $\begin{array}{l}\text { Select new } \\
\text { managers }\end{array}$ & 2.54 & 2.25 & & & \\
\hline Total average & 3.20 & 2.83 & Total average & 3.68 & 3.31 \\
\hline
\end{tabular}

$\mathrm{N}=202$ (using listwise exclusion)

Average task importance:

$1=$ little importance, $5=$ high importance

Average board task performance: $1=$ bad, little attention, 5 = very good score, sufficient attention The individual tasks are ranked on basis of average scores of the board task performance on the respective tasks. For each task, t-tests have shown that the mean average performance of the board of directors and the average importance are significantly different at $\mathrm{p}=0.01$. 